\title{
Inhibition of gonadotrophin release in mares during the luteal phase of the oestrous cycle by endogenous opioids
}

\author{
C. Behrens ${ }^{1}$, J. E. Aurich ${ }^{1}$, E. Klug ${ }^{2}$, H. Naumann ${ }^{3}$ and \\ H-O. Hoppen ${ }^{4}$ \\ ${ }^{1}$ Klinik für Geburtshilfe und Gynäkologie des Rindes, ${ }^{2}$ Klinik für Pferde and ${ }^{4}$ Abteilung für \\ Endokrinologie, Tierärztliche Hochschule, Hannover; and ${ }^{3}$ Hauptgestüt Sachsen-Anhalt, Radegast, \\ Germany
}

\begin{abstract}
Effects of the opioid antagonist naloxone on concentrations of LH and FSH in plasma were measured in mares during different stages of the oestrous cycle. During the follicular phase of the cycle, naloxone ( $300 \mathrm{mg}$ i.v.) had no discemible effects on basal concentrations of $\mathrm{LH}$ and FSH. A significant increase in plasma LH $(P<0.01)$ and FSH $(P<0.05)$ concentrations was observed after naloxone in mares during the luteal phase. This response was not different between suckled and non-suckled mares. The gonadotrophin-releasing hormone analogue buserelin $(0.02 \mathrm{mg}$ i.v.) caused a significant $(P<0.05) \mathrm{LH}$ and FSH release irrespective of the stage of the oestrous cycle and a previous naloxone treatment. The results of this study indicate that endogenous opioid peptides are involved in the inhibition of $\mathrm{LH}$ and FSH release during the luteal phase of the oestrous cycle in mares and may partially mediate the suppressive influence of progesterone on gonadotrophin secretion. The opioid-mediated suppression of LH and FSH release does not seem to be affected by suckling.
\end{abstract}

\section{Introduction}

Endogenous opioid peptides appear to be involved in the regulation of gonadotrophin release. It has been suggested that opioids inhibit the release of $\mathrm{LH}$ in cyclic women (Quigley and Yen, 1980; Blankstein et al., 1981) and other primates (Orstead et al., 1987), rats (Petraglia et al., 1986; Allen et al., 1988), sheep (Currie and Rawlings, 1987; Malven and Hudgens, 1987), pigs (Barb et al., 1986) and cattle (Short et al., 1987) on the basis of opioid antagonists increasing concentrations of $\mathrm{LH}$ in blood. However, there are differences between species. The opioidergic modulation of LH secretion is influenced by gonadal steroids and changes with the stage of the oestrous cycle. Whereas in all species investigated opioids inhibit $\mathrm{LH}$ release during either the luteal or parts of the follicular phase, an opioid influence on the secretion of FSH is less clear, but could be demonstrated in humans (Blankstein et al., 1981) and rats (Bedran de Castro et al., 1986). In addition to certain stages of the oestrous cycle, opioids inhibit LH secretion during postpartum anoestrus. The opioid mediated suppression of LH release depends on suckling in cows (Whisnant et al, 1986) and sows (Armstrong et al,, 1988) and is independent of the suckling stimulus in sheep (Malven and Hudgens, 1987).

The oestrous cycles of mares and other domestic animals differ in several aspects. In contrast to pigs and cattle, horses have a seasonal breeding activity and a prolonged transitional period between winter anoestrus and cyclic ovarian activity. A gradual preovulatory increase in $\mathrm{LH}$ secretion begins about 4 days before ovulation (Miller $e$ t al., 1980) and oestrus lasts for 2

Received 2 September 1992. to 11 days with a mean of 7 days (Adams and Bosu, 1988). The duration of oestrus in mares is therefore longer and much more variable than in rats, domestic ruminants and pigs.

In this study we investigated the influence of the opioid antagonist naloxone on $\mathrm{LH}$ and FSH release in mares at different stages of the oestrous cycle and whether these effects are different in suckled and non-suckled mares. If endogenous opioids participate in the regulation of LH and FSH secretion, naloxone should lead to an increased release of gonadotrophins.

\section{Materials and Methods}

\section{Animals}

Brood mares $(n=25)$ of the Hanoverian breed, aged between 3 and 12 years $(7.3 \pm 2.7$ years, $\pm \mathrm{SD})$, were used. The weight of the mares was $590 \pm 21 \mathrm{~kg}( \pm \mathrm{SD})$. Animals belonged to the stud farm of the state of Sachsen-Anhalt (Radegast). Horses were housed in loose boxes and were fed oats and hay three times daily, water was freely available.

Mares were teased for oestrous behaviour with a stallion three times a week. Ovaries were examined for follicles and corpora lutea by rectal palpation and ultrasound scanning with a $5 \mathrm{MHz}$ linear scanner (Aloka; Eickemeyer, Tuttlingen).

Mares were considered to be in the follicular phase when they showed oestrous behaviour (immobile stance, clitoral winking, tail raise) during teasing, had a follicle with a diameter of $>30 \mathrm{~mm}$ and a plasma progesterone concentration of $<0.8 \mathrm{ng} \mathrm{m}^{-1}$. Mares were considered to be in the luteal phase when they had not shown oestrous behaviour for 6 to 12 days, 
a corpus luteum was detectable by ultrasound examination and the progesterone concentration in plasma was $>0.8 \mathrm{ng} \mathrm{ml}^{-1}$ (see Table 1). Mares at oestrus and at the luteal phase were randomly assigned to the experimental or control groups.

\section{Experimental protocol}

A total of 41 treatments were performed between April and June 1992. Sixteen mares were used twice, that is during the follicular and luteal phase.

An indwelling catheter was placed in the left jugular vein $15 \mathrm{~min}$ before taking the first blood sample. During sampling mares were left in their stables. In suckled mares, the foals were present during the experiment.

Blood samples for determination of $\mathrm{LH}$ and FSH were taken at $15 \mathrm{~min}$ intervals for $4 \mathrm{~h}$. After $60 \mathrm{~min}$ of sampling, naloxone$\mathrm{HCl}$ (300 mg per mare; Sigma, Deisenhofen) or $10 \mathrm{ml}$ of saline were injected via the catheter into the jugular vein. Naloxone was freshly dissolved in $10 \mathrm{ml}$ of saline and sterile filtered. Two hours after injections of naloxone or saline, $20 \mu \mathrm{g}$ of the GnRH analogue buserelin (Receptal: Hoechst, Unterschleißheim) was administered to all animals and blood samples were collected for another $60 \mathrm{~min}$ (i.e. until $180 \mathrm{~min}$ after naloxone or saline). Plasma progesterone and oestradiol concentrations were measured in the first sample taken on each day.

Blood was collected into polystyrol tubes containing $25 \mathrm{mg}$ EDTA. Samples were centrifugated immediately for $20 \mathrm{~min}$ at $1000 \mathrm{~g}$; plasma was frozen at $-20^{\circ} \mathrm{C}$ and was assayed within 3 weeks.

\section{Hormone analysis}

Concentrations of LH in plasma were measured by radioimmunoassay as described by Pantke et al. (1991) with an antibody raised in rabbits against equine $\mathrm{LH}$ (UCB, Braine l'Alleu). The antiserum was diluted in $0.14 \mathrm{~mol} \mathrm{NaCl} \mathrm{l}^{-1}, 0.01 \mathrm{~mol}$ $\mathrm{NaH}_{2} \mathrm{PO}_{4} \mathrm{l}^{-1}$ (PBS; pH 7.2), containing $1 \%$ (v/v) normal rabbit serum. Crossreactivity of the antibody with FSH was less than $0.1 \%$. Plasma samples $(50 \mu \mathrm{l})$ or standards $(100 \mu \mathrm{l}$; UCB) were incubated with $100 \mu \mathrm{l}$ antiserum in a total of $300 \mu \mathrm{l}$ PBS containing $1 \%(\mathrm{w} / \mathrm{v}) \mathrm{BSA}$ for $24 \mathrm{~h}$ at room temperature. The standard preparation used has also been validated in an $\mathrm{LH}$ bioassay in vitro (Pantke et al., 1991). Final dilution of the antiserum was 1:85 000. For determination of nonspecific binding, normal rabbit serum was added instead of antiserum. ${ }^{125} \mathrm{I}$ labelled equine $\mathrm{LH}$, prepared with the chloramine-T method (Greenwood et al., 1963) was used as tracer at a dilution of 20000 c.p.m. in $100 \mu$ l PBS containing I\% BSA. After addition of the tracer, incubation was continued for another $24 \mathrm{~h}$ at $4^{\circ} \mathrm{C}$. Bound ligands were precipitated by adding $200 \mu \mathrm{l}$ of sheep anti-rabbit IgG at a dilution of $1: 20$ in PBS containing $6 \%(\mathrm{w} / \mathrm{v})$ polyethylene glycol (molecular weight 20000 ). Incubation was continued for $1 \mathrm{~h}$ at room temperature and $30 \mathrm{~min}$ at $4^{\circ} \mathrm{C}$. Bound and free ligands were separated by centrifugation at $4^{\circ} \mathrm{C}$ for $20 \mathrm{~min}$ and $2000 \mathrm{~g}$. The supernatant was discarded and radioactivity in the pellet measured in a gamma-counter (Multigamma 1261: Pharmacia, Freiburg). The minimal detectable concentration of this assay was $0.5 \mathrm{ng} \mathrm{ml}^{-1}$, zero binding was $25 \%$ and intra- and interassay coefficients of variation were, respectively, $5.8 \%$ and $18.1 \%$.
FSH was measured by radioimmunoassay with an antiserum raised in rabbits against equine FSH (RB 530: H. Papkoff, University of California) and an equine FSH standard preparation (E276B: H. Papkoff). The antiserum was used at a final dilution of $1: 80000$ in $0.14 \mathrm{~mol} \mathrm{NaCl}^{-1}, 0.001 \mathrm{~mol} \mathrm{NaH} \mathrm{PO}_{4}$ $\mathrm{l}^{-1}(\mathrm{pH} 7.2)$ containing $1 \%(\mathrm{v} / \mathrm{v})$ normal rabbit serum. Crossreactivity of the antibody with $\mathrm{LH}$ was $2.8 \%$. ${ }^{\mathrm{I} 25} \mathrm{I}$-labelled FSH, prepared by the chloramine-T method (Greenwood et al., 1963), was used as tracer at a dilution of 20000 c.p.m. in $100 \mu$ l. The assay procedure for FSH was similar to that described for $\mathrm{LH}$ with the modification that $25 \mu$ instead of $50 \mu \mathrm{l}$ plasma was used. The minimal detectable concentration of the radioimmunoassay for FSH was $0.15 \mathrm{ng} \mathrm{ml}^{-1}$; zero binding was $20 \%$ and intra- and interassay coefficients of variation were $7.9 \%$ and $8.4 \%$, respectively.

Progesterone was determined by radioimmunoassay after extraction from plasma $(0.1 \mathrm{ml})$ with $n$-hexane $(1 \mathrm{ml})$. The antibody crossreacted $51.5 \%$ with 11-dehydroprogesterone, $34.0 \%$ with $17 \alpha$-hydroxyprogesterone, $2.2 \%$ with $16 \alpha$-hydroxyprogesterone and less than $0.9 \%$ with $20 \alpha$-dihydroprogesterone, pregnenolone, $17 \alpha$-hydroxypregnenolone, corticosterone, cortisol, aldosterone, testosterone, androstendione, oestradiol, $17 \alpha$-oestradiol, oestrone and oestriol. Dried down sample extracts were resuspended in $100 \mu \mathrm{l} 0.01$ mol $\mathrm{NaH}_{2} \mathrm{PO}_{4} \mathrm{l}^{-1}$, containing $0.01 \mathrm{~mol} \mathrm{EDTA}^{-1}$ and $0.1 \%(\mathrm{w} / \mathrm{v})$ gelatine ( $\mathrm{pH} 7.2$ ). $\left[1,2,6,7-{ }^{3} \mathrm{H}\right]$ progesterone (Amersham Buchler, Braunschweig) at a dilution of 7000 c.p.m. in $100 \mu \mathrm{l}$ and antiserum at a dilution of $1: 50000$ in $100 \mu \mathrm{l}$ were added. After incubation at $4^{\circ} \mathrm{C}$ for $18 \mathrm{~h}$, free and bound ligands were separated by dextran-coated charcoal. The supernatant was mixed with $1 \mathrm{ml}$ liquid scintillation fluid (Ready Organic, Beckman Instruments, Munich) and radioactivity was measured in a $\beta$-counter. The minimal detectable concentration was $50 \mathrm{pg} \mathrm{ml}^{-1}$; zero binding was $42 \%$ and intra- and interassay coefficients of variation were $4.5 \%$ and $9.7 \%$, respectively.

Oestradiol was extracted from plasma $(0.3 \mathrm{ml})$ with ethylacetate $(3 \mathrm{ml})$ and determined by radioimmunoassay. The antiserum (GDN 244: G. Niswender, Colorado State University) was used at a final dilution of $1: 250000$. Crossreactivity was $52 \%$ with 4-hydroxyoestradiol, $22 \%$ with 2 -hydroxyoestradiol, $2.8 \%$ with 4-hydroxyoestrone, $1.8 \%$ with oestrone, $1.0 \%$ with oestriol, $0.9 \%$ with $17 \alpha$-oestradiol, $0.1 \%$ with 2 -hydroxyoestrone, $0.07 \%$ with $5 \alpha$-dihydrotestosterone and less than $0.02 \%$ with progesterone, 17 $\alpha$-hydroxyprogesterone, pregnenolone, tamoxifen, 4-hydroxytamoxifen, dehydroepiandrosterone, androstendione, testosterone and cortisol. $\left[2,4,6,7-{ }^{3} \mathrm{H}\right]$ oestradiol (Amersham Buchler) was used as tracer at a dilution of 8000 c.p.m. in $100 \mu \mathrm{l}$. The radioimmunoassay was performed as described for progesterone with the modification that $0.01 \mathrm{~mol}$ $\mathrm{NaH}_{2} \mathrm{PO}_{4} 1^{-1}, 0.01 \mathrm{~mol}$ EDTA $1^{-1}, 0.1 \%$ lysozyme (w/v; $\mathrm{pH} 7.2$ ) was used as assay buffer. The minimal detectable concentration was $2 \mathrm{pg} \mathrm{ml}^{-1}$ and zero binding was $44 \%$. Intraand interassay coefficients of variation were $9.5 \%$ and $11.8 \%$, respectively.

\section{Statistical analysis}

Comparisons of $\mathrm{LH}$ and $\mathrm{FSH}$ values between groups were made by analysis of variance for repeated measures. This procedure takes into account the fact that sequential values were 
Table 1. Progesterone and oestradiol concentrations in plasma of mares during the follicular and luteal phases of the oestrous cycle

\begin{tabular}{llccc}
\hline $\begin{array}{l}\text { Phase of } \\
\text { oestrous cycle }\end{array}$ & Group & $\begin{array}{c}\text { Number of animals } \\
\text { (suckled/non-suckled) }\end{array}$ & $\begin{array}{c}\text { Progesterone } \\
\left(\mathrm{ng} \mathrm{ml}^{-1}\right)\end{array}$ & $\begin{array}{c}\text { Oestradiol } \\
\left(\mathrm{pg} \mathrm{ml}^{-1}\right)\end{array}$ \\
\hline Follicular phase & Naloxone & $10(7 / 3)$ & $0.21 \pm 0.15^{\mathrm{a}}$ & $25.8 \pm 11.7^{\mathrm{c}}$ \\
& Saline & $8(5 / 3)$ & $0.23 \pm 0.23^{\mathrm{a}}$ & $30.9 \pm 9.3^{\mathrm{c}}$ \\
Luteal phase & Naloxone & $12(6 / 6)$ & $3.35 \pm 1.98^{\mathrm{b}}$ & $14.4 \pm 8.9^{\mathrm{d}}$ \\
& Saline & $11(4 / 7)$ & $3.17 \pm 1.92^{\mathrm{b}}$ & $16.7 \pm 7.0^{\mathrm{d}}$ \\
\hline
\end{tabular}

Values are means \pm SEM.

$\mathrm{a}, \mathrm{b}$ and $\mathrm{c}, \mathrm{d}$ : Values in the same column with different letters are significantly different $(\mathrm{a}, \mathrm{b}: P<0.001 ; \mathrm{c}, \mathrm{d}: P<0.05$; one-way analysis of variance).

analysed. The analysis was made separately for the periods before naloxone or saline injection, between naloxone or saline and buserelin application and after buserelin treatment. In addition, $\mathrm{LH}$ and FSH concentrations before and after application of buserelin were analysed by paired samples $t$ test, comparing the mean of the four values before buserelin injections with the mean of the four values after buserelin. Progesterone and oestradiol concentrations between groups were compared by one-way analysis of variance. All statistical comparisons were made with the SPCC/PC + statistics package (Norusis, 1988). Values given are means \pm standard error of mean (SEM).

\section{Results}

\section{Steroid hormones}

There were significant differences in plasma progesterone $(P<0.001)$ and oestradiol $(P<0.05)$ concentrations between mares in the luteal and follicular phase of the cycle (see Table 1 ). As can be expected from the experimental design, progesterone values were higher and oestradiol values lower during the luteal phase than during the follicular phase.

\section{LH and FSH}

Concentrations of LH and FSH did not differ significantly between mares that were injected with naloxone and those that received saline during the follicular phase of the oestrous cycle (Fig. 1). Fifteen minutes before injection of naloxone $\mathrm{LH}$ and FSH concentrations were $7.5 \pm 0.7$ and $6.8 \pm 0.9 \mathrm{ng} \mathrm{ml}^{-1}$. respectively. Thirty minutes after naloxone injection plasma $\mathrm{LH}$ concentrations were $7.6 \pm 0.6 \mathrm{ng} \mathrm{ml}^{-1}$ and FSH concentrations $7.1 \pm 1.1 \mathrm{ng} \mathrm{ml}^{-1}$.

Application of $20 \mu \mathrm{g}$ buserelin $2 \mathrm{~h}$ after naloxone resulted in a significant increase $(P<0.05)$ in plasma LH and FSH concentrations in mares of both the control and treatment groups. Fifteen minutes after buserelin plasma LH and FSH concentrations were 10.5 and $10.8 \mathrm{ng} \mathrm{m}^{-1}$, respectively, for mares that received naloxone and $14.0 \pm 2.6$ and $13.5 \pm 2.3 \mathrm{ng} \mathrm{ml}^{-1}$. respectively, for mares that received saline.

During the luteal phase of the cycle, the application of $300 \mathrm{mg}$ of naloxone resulted in a significant increase in $\mathrm{LH}(P<0.01$

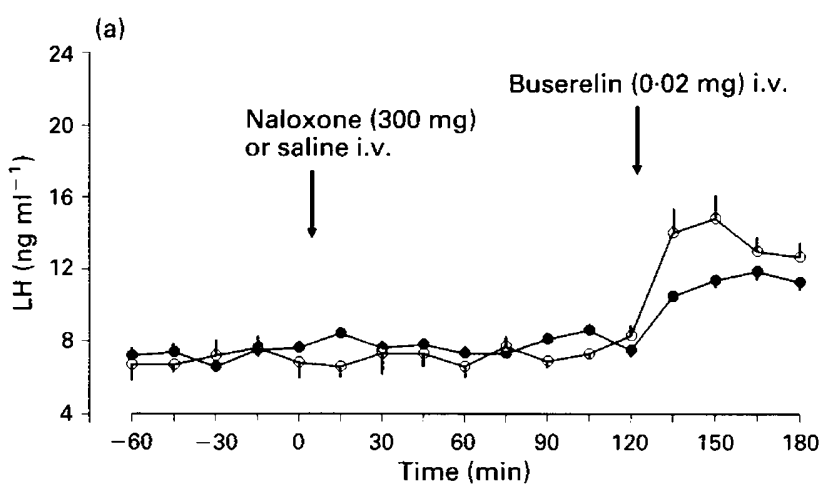

(b)

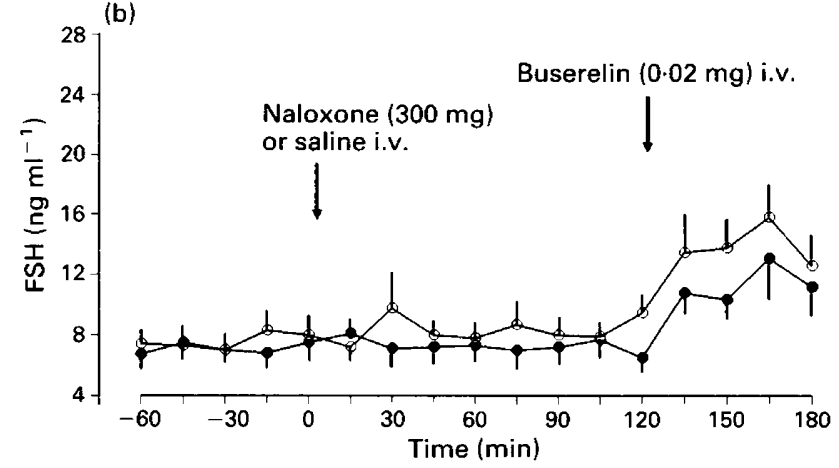

Fig. 1. Concentrations of (a) LH and (b) FSH in plasma of mares during the follicular phase of the oestrous cycle before and after injection of naloxone $(0 ; n=10)$ or saline $(O ; n=8)$ and buserelin; values are means $\pm \mathrm{SEM}$. Analysis of variance for repeated measures showed that differences between groups were not statistically significant. Paired samples $t$ test showed that LH and FSH values before and after injection of buserelin were significantly different for mares in both groups $(P<0.05)$

versus control group, $D F 1,21, F=9.03)$ and FSH $(P<0.05$ versus control group, $D F 1,21, F=6.49$ ) concentrations in plasma (Fig. 2). Fifteen minutes before naloxone, plasma $\mathrm{LH}$ and FSH concentrations were $8.8 \pm 1.0$ and $11.0 \pm 2.2 \mathrm{ng} \mathrm{ml}^{-1}$, respectively. Fifteen minutes after naloxone, concentrations of LH and FSH were $13.7 \pm 4.1$ and $17.9 \pm 8.1 \mathrm{ng} \mathrm{ml}^{-1}$, respectively. Concentrations of both gonadotrophins remained high for $2 \mathrm{~h}$ after naloxone treatment, that is until the administration 
(a)

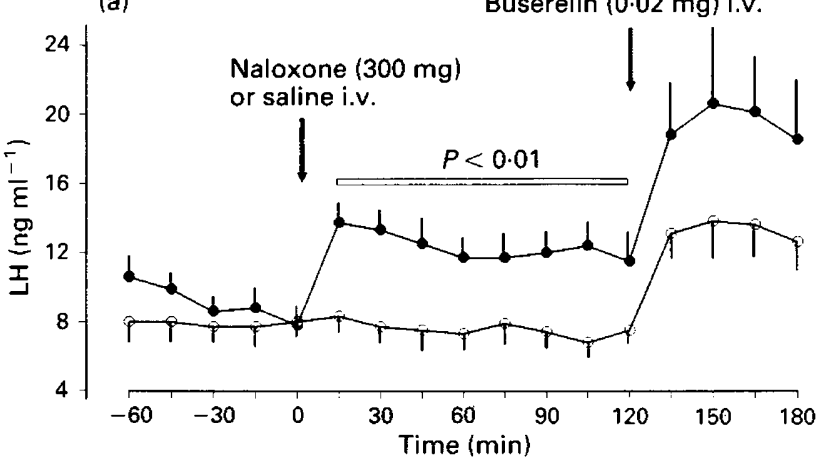

(b)

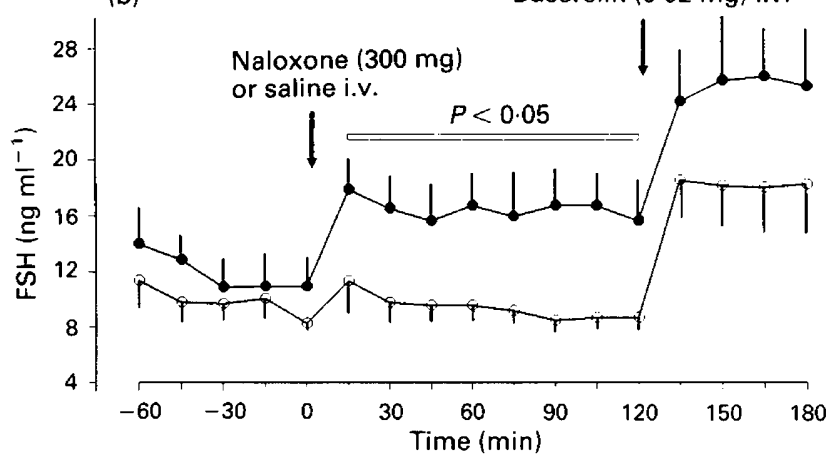

Fig. 2. Concentrations of (a) LH and (b) FSH in plasma of mares during the luteal phase of the oestrous cycle before and after injection of naloxone $(0 ; n=12)$ or saline $(O ; n=11)$ and buserelin; values are means \pm SEM. Analysis of variance for repeated measures showed that values for groups are significantly different from each other for the period after naloxone or saline but before buserelin injections ( $\mathrm{LH}$ $P<0.01$; FSH $P<0.05$ ). Paired samples $t$ test showed that $\mathrm{LH}$ and FSH values before and after injection of buserelin were significantly different for mares in both groups $(P<0.05)$.

of buserelin. Buserelin caused a further significant increase in plasma $\mathrm{LH}$ and FSH concentrations $(P<0.05)$ in mares that had received naloxone and in mares that had received saline. Plasma concentrations of LH and FSH 15 min after injection of buserelin were $18.8 \pm 2.9$ and $24.3 \pm 3.7 \mathrm{ng} \mathrm{ml}^{-1}$, respectively, in horses of the naloxone group. Corresponding values for mares that had received saline were $13.1 \pm 1.6$ and $18.6 \pm 2.7 \mathrm{ng}$ $\mathrm{ml}^{-1}$, respectively.

In non-suckled, luteal phase mares, the increase in gonadotrophin values tended to be higher than in suckled, luteal phase mares, but differences were not statistically significant (Fig. 3).

\section{Discussion}

In this study we measured concentrations of LH and FSH in plasma of mares at different stages of the oestrous cycle before and after application of the opiate antagonist naloxone. Naloxone led to an increase in circulating LH and FSH concentrations in mares in the luteal phase but not in the follicular phase. These observations suggest that opioid peptides are
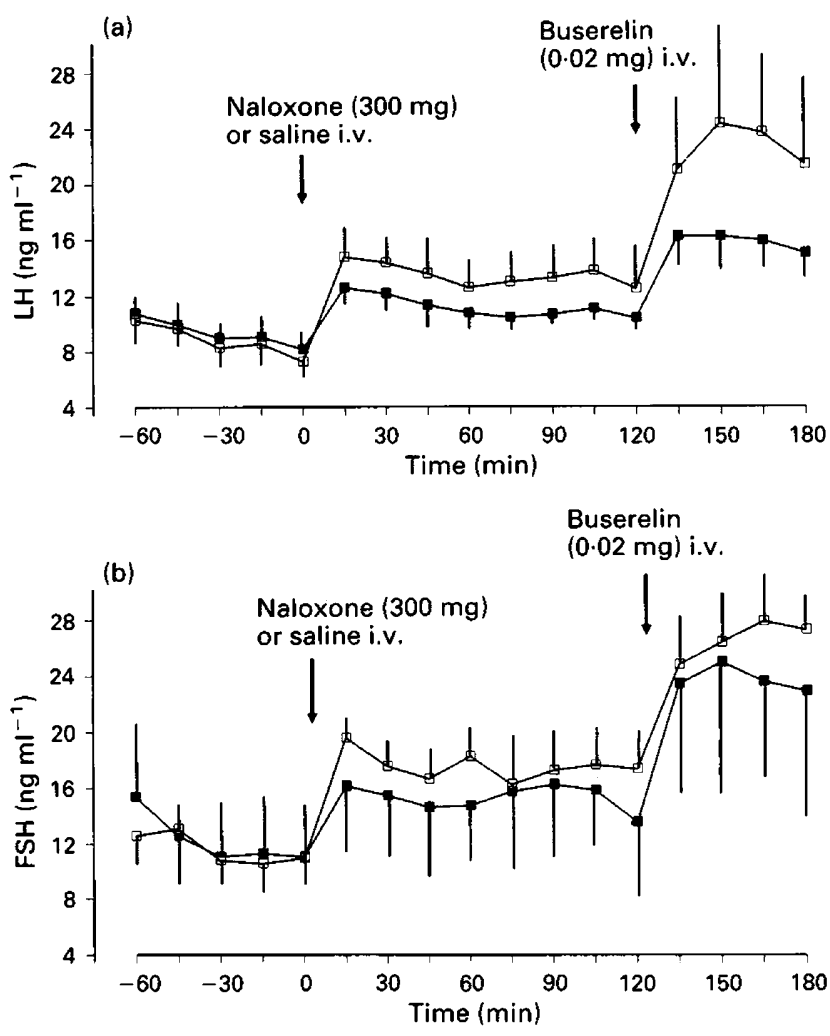

Fig. 3. Concentrations of (a) LH and (b) FSH in plasma of suckled ( $n=6)$ and non-suckled mares $(\square ; n=6)$ during the luteal phase of the oestrous cycle before and after injection of naloxone and buserelin; values are means \pm SEM. Analysis of variance for repeated measures showed that differences between groups were not statistically significant. Paired samples $t$ test showed that $\mathrm{LH}$ and FSH values before and after injection of buserelin were significantly different for mares in both groups $(P<0.05)$.

involved in the regulation of gonadotrophin secretion during the oestrous cycle in horses.

An inhibitory action of opioid systems on LH release during the luteal phase of the cycle is in agreement with reports from humans (Quigley and Yen, 1980; Blankstein et al., 1981), monkeys (Orstead et al., 1987), rats (Petraglia et al., 1986; Allen et al., 1988), sheep (Currie and Rawlings, 1987; Malven and Hudgens, 1987) and pigs (Barb et al., 1986). Inhibition of LH secretion by opioids was also demonstrated during parts of the follicular phase in humans (Quigley and Yen, 1980; Blankstein et al., 1981) and rats (Petraglia et al., 1986; Allen et al., 1988). The opioid influence on LH release depends on gonadal steroids, especially progesterone. In ovariectomized women (Shoupe et al., 1985) or sheep (Brooks et al., 1986; Trout and Malven, 1987), naloxone influences LH release only after replacement of progesterone alone or with oestrogens. In species with a relatively short follicular phase, such as rats or sheep, oestrogens may act synergistically with residual progesterone from the corpus luteum in stimulating endogenous opioid systems. In mares, the period of high circulating oestrogen concentrations towards the end of oestrus occurs at least a week after luteolysis (Adams and Bosu, 1988). An oestrogenic influence alone does not seem to activate opioid systems involved in the regulation of gonadotrophin release. 
In mares in the luteal phase, naloxone also induced a significant release of FSH. Changes in plasma FSH and LH concentrations occurred in parallel. A comparable effect of opioids on both gonadotrophins in the female has not been found in other species. In humans and rats, FSH release seems to be under some opioidergic control but the effect of opioid antagonists on FSH was less than on LH release. In sheep (Currie and Rawlings, 1987; Horton et al., 1987) and rabbits (Younglai et al, 1988), naloxone did not change plasma FSH concentrations. Opioids inhibit GnRH release from the hypothalamus (Kalra, 1981; Malven et al., 1990). FSH should be affected by opioids in as much as it is under the control of $\mathrm{GnRH}$. The different reaction of $\mathrm{LH}$ and FSH to opioid antagonists has been interpreted as evidence for factors in addition to GnRH that regulate LH and FSH release (Orstead and Spies, 1987; Currie and Rawlings, 1987). In mares, there is a strong coincidence between pulses of GnRH, LH and FSH (Alexander and Irvine, 1987). This is in agreement with a parallel reaction of LH and FSH to opioid receptor blockade in this study. From our results it can be concluded that in mares the negative feedback of progesterone or progesterone and oestrogens on gonadotrophin secretion is mediated at least in part by brain opioid systems. The decrease in circulating progesterone concentrations after luteolysis terminates the opioid inhibition of gonadotrophin release. The subsequent increased gonadotrophin secretion favours follicular development and finally ovulation. It might be argued that the lack of a reaction to naloxone in follicular phase mares could be due to insufficient pituitary gonadotrophin content. However, all mares reacted with a significant $\mathrm{LH}$ and FSH release after injection of a $\mathrm{GnRH}$ agonist. This result demonstrated that pituitary gonadotrophin content was not a limiting factor. It is also possible that a naloxone-induced $\mathrm{LH}$ and $\mathrm{FSH}$ release during the follicular phase was not of sufficient magnitude to be detectable in peripheral plasma.

A differential reaction to naloxone was not found in suckled and non-suckled mares. In pigs and beef cattle lactation is accompanied by a period of anoestrus. It has been suggested that endogenous opioids are released in response to the suckling stimulus and subsequently inhibit gonadotrophin secretion. Suckled sows and cows show an increased LH release after naloxone administration. This effect is no longer present after weaning (Whisnant et al., 1986; Armstrong et al., 1988). In sheep, however, naloxone increased plasma LH concentrations in weaned as well as in suckled ewes (Malven and Hudgens, 1987). In the study reported here, in suckled and non-suckled luteal phase mares LH and FSH concentrations increased after naloxone application. The increase tended to be even higher in the non-suckled mares but differences between suckled and nonsuckled mares were not statistically significant. Our findings are therefore in agreement with results from sheep. In suckled cattle and sows, lactational anoestrus is characterized by the absence of cyclic ovarian activity (Cox and Britt, 1982; Walters et al., 1982). In contrast, in the suckled mare a fertile oestrous cycle is present and suckling does not have a major effect on the opioid inhibition of gonadotrophin release.

This study was supported by the Mehl-Mühlens-Stiftung. The authors are grateful to W. Rudolph and his team at Radegast Stud for care of the horses and to $\mathrm{H}$. Niederstucke and A. Hoppe for help with the hormone assays. We are indebted to $\mathrm{H}$. Papkoff (University of California, San Francisco) for the FSH antiserum and equine FSH standards, to R. Knuppen (Medizinische Universität, Lübeck, Germany) for the progesterone antibody and to G. D. Niswender (Colorado State University, Fort Collins, Colorado, USA) for the oestradiol antiserum.

\section{References}

Adams GP and Bosu WTK (1988) Reproductive physiology of the nonpregnant mare Veterinary Clinics of North America: Equine Practice 4 161-176

Alexander SL and Irvine CHG (1987) Secretion rates and short-term patterns of gonadotrophin-releasing hormone, $\mathrm{FSH}$ and LH throughout the periovulatory period in the mare Joumal of Endocrinology 114 351-362

Allen LG, Hahn E, Caton D and Kalra SP (1988) Evidence that a decrease in opioid tone on proestrus changes the episodic pattern of luteinizing hormone (LH) secretion: implications in the preovulatory LH hypersecretion Endocrinology 122 1004-1013

Armstrong JD, Kraeling RR and Britt JH (1988) Effects of naloxone or transient weaning on secretion of $\mathrm{LH}$ and prolactin in lactating sows Journal of Reproduction and Fertility 83 301-308

Barb CR, Kraeling RR, Rampacek GB and Whisnant CS (1986) Influence of stage of the estrous cycle on endogenous opioid modulation of luteinizing hormone, prolactin, and cortisol secretion Biology of Reproduction 35 1162-1167

Bedran de Castro JC, Khorram O, Petrovic SL and McCann SM (1986) Role of opioid peptides in pulsatile release of gonadotropins and prolactin in the rat Brain Research Bulletin 19 539-544

Blankstein J, Reyes FI, Winter JD and Faiman C (1981) Endorphins and the regulation of the human menstrual cycle Clinical Endocrinology 14 287-294

Brooks AN, Haynes NB, Yang K and Lamming GE (1986) Ovarian steroid involvement in endogenous opioid modulation of LH secretion in seasonally anoestrous mature ewes Joumal of Reproduction and Fertility 76 709-715

Cox NM and Britt JH (1982) Relationships between endogenous gonadotropinreleasing hormone, gonadotropins and follicular development after weaning in sows Biology of Reproduction 26 70-78

Currie WD and Rawlings NC (1987) Naloxone enhances LH but not FSH release during various phases of the estrous cycle Life Sciences 41 1207-1214

Greenwood FC, Hunter WM and Glover JS (1963) The preparation of ${ }^{13}$ I-labelled growth hormone of high specific radioactivity Biochemical Journal 89 114-123

Horton RJE, Cummins JT and Clarke IJ (1987) Naloxone evokes large-amplitude $\mathrm{GnRH}$ pulses in luteal phase ewes Journal of Reproduction and Fertility $\mathbf{8 1}$ 277-286

Kalra SP (1981) Neural loci involved in naloxone-induced luteinizing hormone release: effects of a norepinephrine synthesis inhibitor Endocrinology 109 1805-1810

Malven PV and Hudgens RE (1987) Naloxone-reversible inhibition of luteinizing hormone in postpartum ewes: effects of suckling and season Journal of Animal Science 65 196-202

Malven PV, Stanisiewski EP and Haglof SA (1990) Ovine brain areas sensitive to naloxone-induced stimulation of luteinizing hormone Neuroendocrinology $\mathbf{5 2}$ 373-381

Miller KF, Berg SL, Sharp DC and Ginther OJ (1980) Concentrations of circulating gonadotropins during various reproduction states in mares Biology of Reproduction 22 744-750

Norusis MJ (1988) SPSS/Pc + for the IBM PC/XT/AT and PS2. SPSS Inc., Chicago

Orstead KM and Spies HG (1987) Inhibition of hypothalamic gonadotropinreleasing hormone release by endogenous opioid peptides in the female rabbit Neuroendocrinology 46 14-23

Orstead KM, Hess DL and Spies HG (1987) Opiatergic inhibition of pulsatile luteinizing hormone release during the menstrual cycle of rhesus macaques Proceedings of the Society for Experimental Biology and Medicine 184 312-319

Pantke P, Hyland J, Galloway DB, MacLean AA and Hoppen H-O (1991) Changes in luteinizing hormone bioactivity associated with gonadotrophin pulses in the cyclic mare Journal of Reproduction and Fertility Supplement 44 13-18

Petraglia F, Locatelli V, Facchinetti F, Bergamaschi M, Genzzani AR and Cocchi D (1986) Oestrous cycle-related LH responsiveness to naloxone: effect of high oestrogen levels on the activity of opioid receptors Journal of Endocrinology 108 89-94 
Quigley ME and Yen SSC (1980) The role of endogenous opiates on LH secretion during the menstrual cycle Joumal of Clinical Endocrinology and Metabolism 51 179-181

Short RE, Brooks AN, Peters AR and Lamming GE (1987) Opioid modulation of LH secretion during the oestrous cycle of heifers Joumal of Reproduction and Fertility $80213-219$

Shoupe D, Montz FJ and Lobo RA (1985) The effects of estrogen and progestin on endogenous opioid activity in oophorectomized women Joumal of Clinical Endocrinology and Metabolism 60 178-183

Trout WE and Malven PV (1987) Effects of exogenous estradiol-17 $\beta$ and progesterone on naloxone-reversible inhibition of the release of luteinizing hormone in ewes Journal of Animal Science 65 1602-1609
Walters DL, Kaltenbach CC, Dunn TG and Short RE (1982) Pituitary and ovarian function in postpartum beef cows. I. Effect of suckling on serum and follicular fluid hormones and follicular gonadotropin receptors Biology of Reproduction $26640-646$

Whisnant CS, Kiser TE. Thompson FN and Barb CR (1986) Influence of calf removal on the serum luteinizing hormone response to naloxone in the postpartum beef cow Journal of Animal Science 63 561-564

Younglai EV, Wilkinson M, Thompson N and Byrne A (1988) Opioidergic control of luteinizing hormone secretion in the female rabbit: influence of age on the response to naloxone Canadian Journal of Physiology and Pharmacology $6638-42$ 